\title{
Effects of supplementing condensed tannin extract on intake, digestion, ruminal fermentation, and milk production of lactating dairy cows ${ }^{1}$
}

\author{
C. M. Dschaak, ${ }^{\star}$ C. M. Williams, ${ }^{*}$ M. S. Holt, ${ }^{\star}$ J.-S. Eun, ${ }^{2}$ A. J. Young, ${ }^{*}$ and B. R. Min† \\ *Department of Animal, Dairy, and Veterinary Sciences, Utah State University, Logan 84322 \\ †Department of Agricultural and Environmental Sciences, Tuskegee University, Tuskegee, AL 36088
}

\begin{abstract}
A lactation experiment was conducted to determine the influence of quebracho condensed tannin extract (CTE) on ruminal fermentation and lactational performance of dairy cows. The cows were fed a high forage (HF) or a low forage (LF) diet with a forageto-concentrate ratio of 59:41 or 41:59 on a dry matter (DM) basis, respectively. Eight multiparous lactating Holstein cows ( $62 \pm 8.8 \mathrm{~d}$ in milk) were used. The design of the experiment was a double $4 \times 4$ Latin square with a $2 \times 2$ factorial arrangement of treatments, and each period lasted $21 \mathrm{~d}$ (14 d of treatment adaptation and $7 \mathrm{~d}$ of data collection and sampling). Four dietary treatments were tested: HF without CTE, HF with CTE $(\mathrm{HF}+\mathrm{CTE}), \mathrm{LF}$ without CTE, and LF with CTE (LF+CTE). Commercial quebracho CTE was added to the $\mathrm{HF}+\mathrm{CTE}$ and the $\mathrm{LF}+\mathrm{CTE}$ at a rate of $3 \%$ of dietary DM. Intake of DM averaged $26.7 \mathrm{~kg} / \mathrm{d}$ across treatments, and supplementing CTE decreased intakes of DM and nutrients regardless of forage level. Digestibilities of DM and nutrients were not affected by CTE supplementation. Milk yield averaged $35.3 \mathrm{~kg} / \mathrm{d}$ across treatments, and yields of milk and milk component were not influenced by CTE supplementation. Negative effects of CTE supplementation on feed intake resulted in increased feed efficiency (milk yield/DM intake). Although concentration of milk urea N (MUN) decreased by supplementing CTE in the diets, efficiency of $\mathrm{N}$ use for milk $\mathrm{N}$ was not affected by CTE supplementation. Feeding the LF diet decreased ruminal $\mathrm{pH}$ (mean of 6.47 and 6.33 in HF and LF, respectively). However, supplementation of CTE in the diets did not influence ruminal pH. Supplementing CTE decreased total volatile fatty acid concentration regardless of level of forage. With CTE supplementation, molar proportions of acetate, propionate, and butyrate increased in the HF diet, but not in the LF diet, resulting in interac-
\end{abstract}

\footnotetext{
Received September 13, 2010.

Accepted January 27, 2011.

${ }^{1}$ Approved as Journal Paper Number 8245 of the Utah Agricultural Experiment Station, Utah State University, Logan.

${ }^{2}$ Corresponding author: jseun@usu.edu
}

tions between forage level and CTE supplementation. Concentration of ammonia- $\mathrm{N}$ tended to decrease with supplementation of CTE. The most remarkable finding in this study was that cows fed CTE-supplemented diets had decreased ruminal ammonia-N and MUN concentrations, indicating that less ruminal $\mathrm{N}$ was lost as ammonia because of decreased degradation of crude protein by rumen microorganisms in response to CTE supplementation. Therefore, supplementation of CTE in lactation dairy diets may change the route of $\mathrm{N}$ excretion, having less excretion into urine but more into feces, as it had no effect on $\mathrm{N}$ utilization efficiency for milk production.

Key words: condensed tannin extract, lactating dairy cow, milk urea-N, ammonia- $\mathrm{N}$

\section{INTRODUCTION}

In ruminants fed high-quality forage diets, most proteins are rapidly solubilized releasing between 56 and $65 \%$ of the $\mathrm{N}$ concentration in the rumen during fermentation; consequently, large losses of $\mathrm{N}$ occur $(25-35 \%)$ as ammonia $\left(\mathrm{NH}_{3}\right)$ into urine (Min et al., 2000). Research is needed to improve $\mathrm{N}$ retention in animals. Natural plant compounds with a known ability to reduce proteolysis such as condensed tannin extract (CTE) offer a promising means of achieving this goal. Aerts et al. (1999a) found that condensed tannins (CT) in birdsfoot trefoil (Lotus corniculatus) and big trefoil (Lotus pedunculatus) markedly protected ribulose-1,5-bisphosphate carboxylase/oxygenase from degradation by mixed rumen microorganisms. Molan et al. (2001) demonstrated that CT concentrations of $400 \mu \mathrm{g} / \mathrm{mL}$ or greater reduced the growth of a range of bacterial strains from the rumen. Furthermore, Min et al. (2002) reported that when the diet was changed from perennial ryegrass-white clover pasture (which does not contain CT) to birdsfoot trefoil $(3.2 \% \mathrm{CT}$ on DM basis) in sheep, populations of the proteolytic rumen bacteria decreased, confirming that the $\mathrm{CT}$ in the forages greatly reduces rumen proteolytic bacterial growth. These effects of $\mathrm{CT}$ on retarding forage $\mathrm{N}$ degradation supported greater milk production from cows fed birdsfoot trefoil over alfalfa silage (Hymes- 
Fecht et al., 2005). Alfalfa does not produce tannins except in the seed coats. Thus, feeding CT-containing forages in the diets containing alfalfa as a main forage source may increase $\mathrm{N}$ utilization and improve animal performance. However, tannin-rich forages are not agronomically suited in many areas and thus may not be readily available. Hence, a concentrated source of CT may be a possible alternative approach to feeding tannin-rich forages to enhance $\mathrm{N}$ utilization and improve lactational performance of dairy cows if similar dietary concentrations of tannins are provided from CTE as is seen in tannin-rich forage diets.

Although supplementation of CTE in lactating dairy diets has been extensively investigated, the literature lacks information on how ruminal fermentation characteristics are altered depending upon dietary composition, particularly forage-to-concentrate-ratio, which is considered one of the main driving forces directly affecting ruminal fermentation and production performance of lactating dairy cows. In addition, some studies (Jones et al., 1994; Molan et al., 2001) have shown that CT from different legume forages inhibit cell growth and division of ruminal microorganisms, including $\mathrm{Bu}$ tyrivibrio fibrisolvens, which is among those responsible for ruminal biohydrogenation (Jenkins et al., 2008). Grazing birdsfoot trefoil versus perennial ryegrass led to increased concentrations of C12:0, C14:0, C16:0, C18:2 n-6, and C18:3 n-3 fatty acids (FA), and reduced concentrations of cis-9 C18:1, cis-9, trans-11 conjugated linoleic acids (CLA), and trans-11 C18:1 FA in milk (Turner et al., 2005). The ruminal microbial population is an integral system with numerous interrelationships. Thus, it is likely that the inhibitory effects of CT influence ruminal biohydrogenation of unsaturated FA, leading to an altered biohydrogenation pathway (Vasta et al., 2008) and, consequently, changes in the FA composition of milk.

We hypothesized that supplementation of CTE would decrease ruminal $\mathrm{NH}_{3}$ concentration and improve utilization of $\mathrm{N}$ for milk production, but its effects would differ between high $(\mathbf{H F})$ and low forage $(\mathbf{L F})$ diets. The objective of this study was to assess ruminal fermentation characteristics, digestibility, and lactational performance of early to mid lactating dairy cows fed an HF or LF diet without or with CTE supplementation. Additionally, we were interested in a possible link between supplementation of CTE and milk FA composition.

\section{MATERIALS AND METHODS}

The dairy cows used in this study were cared for according to the Live Animal Use in Research Guidelines of the Institutional Animal Care and Use Committee at Utah State University (Logan).

\section{Cows, Experimental Design, and Diets}

Eight multiparous lactating Holstein cows were used; 4 cows were surgically fitted with ruminal cannulas. Days in milk ranged from 52 to 68 and from 49 to 73 for noncannulated and cannulated cows, respectively, at the start of the experiment. Average BW was $692 \pm$ $69.7 \mathrm{~kg}$ at the beginning of the experiment and $710 \pm$ $75.9 \mathrm{~kg}$ at the end of the experiment.

The design of the experiment was a double $4 \times 4$ Latin square with each period lasting $21 \mathrm{~d}$ (14 d of treatment adaptation and $7 \mathrm{~d}$ of data collection and sampling). The cows were allocated to squares by whether they were surgically cannulated, and the 2 squares were conducted simultaneously. Within square, cows were randomly assigned to a sequence of 4 diets. A $2 \times 2$ factorial arrangement was used; HF or LF diet with a forage-to-concentrate ratio of 59:41 or 41:59 (DM basis; Table 1), respectively, was combined without or with CTE to form 4 treatments: HF diet without CTE (HF-CTE), HF diet with CTE (HF+CTE), LF diet without CTE (LF-CTE), and LF diet with CTE $(\mathbf{L F}+\mathbf{C T E}$; Table 1). Water-soluble quebracho CTE in powder form (99\% solubility; Chemtan Company Inc., Exeter, NH) was a crude extract of the bark of Shinopsis spp., and the appropriate quantity of quebracho CTE was applied into the mixer wagon to be mixed with other ingredients added to the $\mathrm{HF}+\mathrm{CTE}$ and $\mathrm{LF}+\mathrm{CTE}$ diets at a rate of $3 \% \mathrm{DM}$. The same quebracho $\mathrm{CTE}$ product was reported to contain $75 \% \mathrm{CT}$ concentration with a small amount of simple phenolics (Min et al., 2006).

The forages used were alfalfa hay and corn silage; Table 1 shows diet composition. The concentrate contained steam-flaked barley and a pelleted supplement, and the formulation of the concentrate differed for the LF and HF diets. The diets are typical of high-producing cow diets in northern Utah with the inclusion of Rumensin (approximately $300 \mathrm{mg} /$ head per day; Elanco Animal Health, Greenfield, IN), and were formulated based on NRC (2001) recommendations to provide sufficient $\mathrm{NE}_{\mathrm{L}}, \mathrm{MP}$, vitamins, and minerals to produce $40 \mathrm{~kg} / \mathrm{d}$ of milk with $3.5 \%$ fat and $3.0 \%$ true protein.

Cows were housed in individual tie stalls fitted with rubber mattresses and bedded with straw, and were fed a TMR for ad libitum intake with at least $10 \%$ of daily feed refusal. All cows were individually fed twice daily at 0830 and $1500 \mathrm{~h}$ with approximately 70 and $30 \%$ of total daily feed allocation at each feeding, respectively. Feed offered and refused was recorded daily, and daily 
Table 1. Ingredients and chemical composition (means $\pm \mathrm{SD})$ of the TMR fed to lactating cows $(\mathrm{n}=4)$

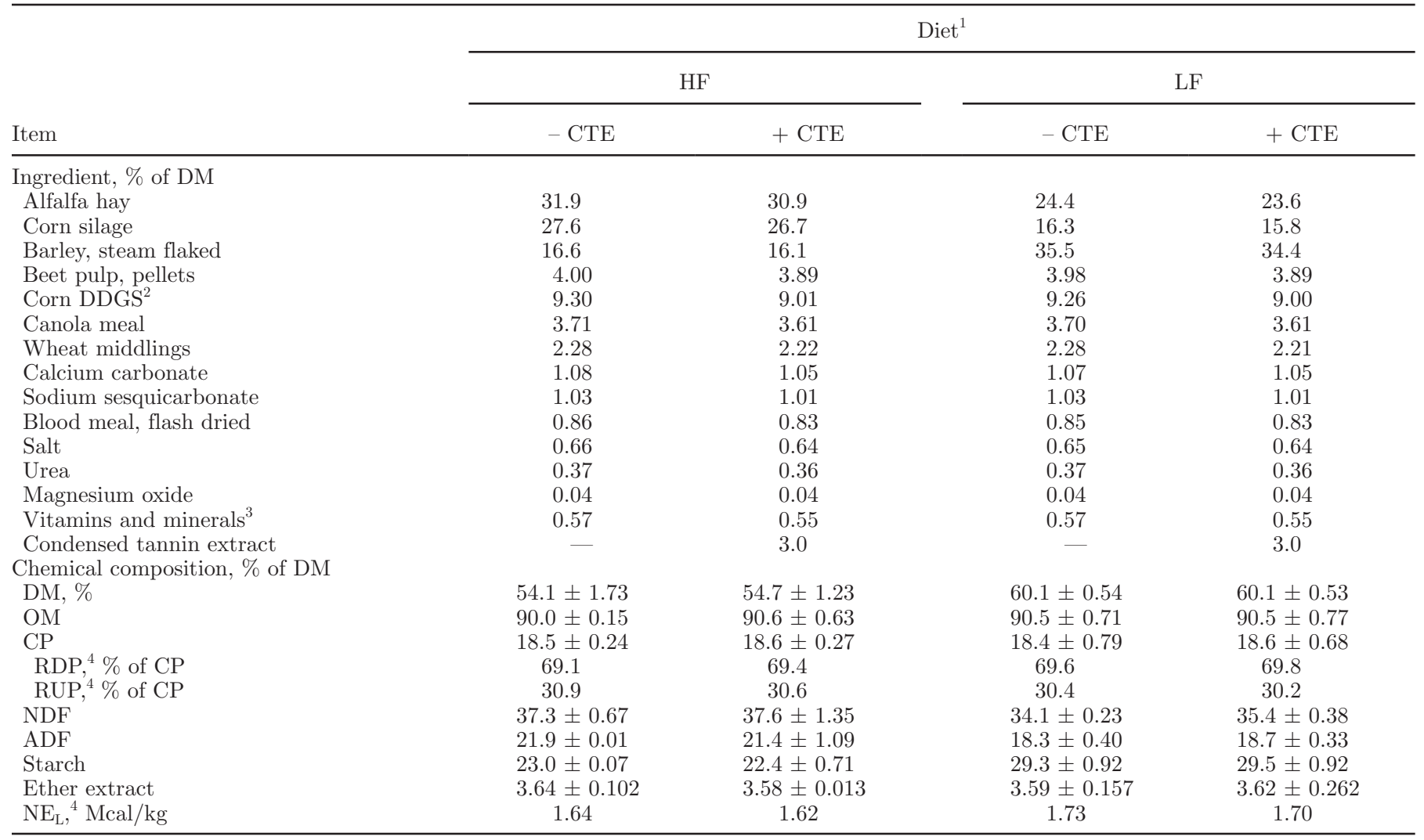

${ }^{1}$ Diets: high forage (HF) and low forage (LF) with (+ CTE) and without (- CTE) condensed tannin extract.

${ }^{2}$ Dried distillers grains with solubles.

${ }^{3}$ Formulated to contain (per kilogram of DM): $71.3 \mathrm{~g}$ of P, $68.9 \mathrm{~g}$ of K, $94.6 \mathrm{mg}$ of Se (from sodium selenate), $6.56 \mathrm{~g}$ of Cu (from copper sulfate), $25.8 \mathrm{~g}$ of $\mathrm{Zn}$ (from zinc sulfate), 4,131.3 $\mathrm{kIU}$ of vitamin A, 515.4 kIU of vitamin D, 5,728.8 IU of vitamin E, and $19.6 \mathrm{mg}$ of Rumensin (Elanco Animal Health, Greenfield, IN).

${ }^{4}$ Based on tabular value (NRC, 2001).

samples were collected to determine DMI. Cows had free access to water.

Cows were milked twice daily at 0400 and $1600 \mathrm{~h}$. Milk production was recorded daily throughout the experiment. Cows were turned outside to a drylot for exercise for at least $1 \mathrm{~h}$ daily in the morning after being milked. Milk was sampled during the a.m. and p.m. milkings on 2 consecutive days (d 16 and 17) in each period. Individual milk samples were analyzed for fat, true protein, lactose, and MUN by the Rocky Mountain DHIA Laboratory (Logan, UT). Milk composition was expressed on weighted milk yield of a.m. and p.m. samples. Yields of milk fat, true protein, and lactose were calculated by multiplying milk yield from the respective day by fat, true protein, and lactose concentrations of the milk from an individual cow.

\section{Sampling, Data Collection, and Chemical Analyses}

Chopped alfalfa hay, corn silage, and concentrates were sampled weekly to determine DM concentration.
Diets were adjusted weekly to account for changes in DM concentration. Diets of TMR samples were collected on d 20 and 21 for particle size analysis by using the Penn State Particle Separator as described by Kononoff et al. (2003) equipped with 3 sieves $(19,8$, and 1.18 $\mathrm{mm}$ ) and a pan. The recommended proportions for TMR are 2 to $8 \%$ on the $19-\mathrm{mm}$ sieve, 30 to $50 \%$ on the $8-\mathrm{mm}$ sieve, and 30 to $50 \%$ on the $1.18-\mathrm{mm}$ sieve (Kononoff and Heinrichs, 2007). All diets were within the recommended range, except for the proportion on the top screen for the HF diet, which was greater than recommend.

Samples of the TMR fed and orts for individual cows were collected daily during the data collection period, dried at $60^{\circ} \mathrm{C}$ for $48 \mathrm{~h}$, ground to pass a $1-\mathrm{mm}$ screen (standard model 4, Arthur H. Thomas Co., Philadelphia, PA), and stored for subsequent analyses. Contents of DM of the samples were used to calculate intakes and digestibilities of DM and nutrients.

Analytical DM concentration of samples was determined by oven drying at $135^{\circ} \mathrm{C}$ for $3 \mathrm{~h}$; OM was deter- 
mined by ashing, and $\mathrm{N}$ content was determined using an elemental analyzer (Leco TruSpec N, St. Joseph, MI; AOAC, 2000). The NDF and ADF concentrations were sequentially determined using an Ankom ${ }^{200 / 220}$ Fiber Analyzer (Ankom Technology, Macedon, NY) according to the methodology supplied by the company, which is based on the methods described by Van Soest et al. (1991). Sodium sulfite was used in the procedure for NDF determination and pre-treatment with heat-stable amylase (Type XI-A from Bacillus subtilis; Sigma-Aldrich Corporation, St. Louis, MO). Starch concentration of feed was determined by using a 2-step enzymatic method (Rode et al., 1999) with a microtiter plate reader (Dynatech Laboratories, Chantilly, VA) to read glucose release colorimetrically at $490 \mathrm{~nm}$.

Weekly samples of dietary ingredients were analyzed for total FA concentration and FA profile according to the procedure of Sukhija and Palmquist (1988) and Kleinschmit et al. (2007) using a GLC (model 6890 series II, Hewlett Packard Co., Avondale, PA) fitted with a flame-ionization detector. The injector port temperature was $230^{\circ} \mathrm{C}$ with a split ratio of $20: 1$. The column was $100 \mathrm{~m}$, with an inside diameter of $0.25 \mathrm{~mm}$ (CP-Sil 88, Varian, Lake Forest, CA). The carrier gas was helium at a rate of $2.0 \mathrm{~mL} / \mathrm{min}$. Initial oven temperature was $50^{\circ} \mathrm{C}$ held for $1 \mathrm{~min}$, and then increased to $145^{\circ} \mathrm{C}$ at a rate of $5^{\circ} \mathrm{C}$ per min and held for $30 \mathrm{~min}$. The temperature was then increased at $10^{\circ} \mathrm{C} / \mathrm{min}$ to $190^{\circ} \mathrm{C}$ and held for $30 \mathrm{~min}$. Finally, the temperature was increased at $5^{\circ} \mathrm{C} / \mathrm{min}$ to $210^{\circ} \mathrm{C}$ and held for $35 \mathrm{~min}$. The total run per sample lasted $123.5 \mathrm{~min}$.

Weighted composite milk samples from individual cows were analyzed for FA composition. Milk fat was extracted by boiling milk in a detergent solution (Hurley et al., 1987). Extracted fat was derivatized to methyl esters using an alkaline methylation procedure by mixing $40 \mathrm{mg}$ of fat with a sodium methoxide methylation reagent $\left(\mathrm{NaOCH}_{3} / \mathrm{MeOH}\right)$ as described by Chouinard et al. (1999). After FA methyl esters were formed, anhydrous calcium chloride pellets were added and allowed to stand for $1 \mathrm{~h}$ to remove water in the sample. Samples were then centrifuged at $1,016 \times g$ at $4^{\circ} \mathrm{C}$ for $20 \mathrm{~min}$.

Separation of FA was achieved by using a GLC (model 6890 series II) fitted with a flame-ionization detector. Samples containing methyl esters in hexane $(1 \mu \mathrm{L})$ were injected through the split injection port (100:1) onto the column (CP-Sil 88). Oven temperature was set at $80^{\circ} \mathrm{C}$ and held for $10 \mathrm{~min}$, and then increased to $190^{\circ} \mathrm{C}$ at $12^{\circ} \mathrm{C} / \mathrm{min}$ for $39 \mathrm{~min}$. The temperature was then increased again to $218^{\circ} \mathrm{C}$ at $20^{\circ} \mathrm{C} / \mathrm{min}$ and held for $21 \mathrm{~min}$. Injector and detector were set at $250^{\circ} \mathrm{C}$. Total run time was $71 \mathrm{~min}$. Heptadecadenoic acid was used as a qualitative internal standard. Individual FA concentrations were obtained by taking the specific FA area as a percentage of total FA, and were reported as grams per hundred grams of FA methyl esters.

Feed DM and nutrient digestibility was measured during the last week in each period using acid-insoluble ash (AIA) as an internal marker (Van Keulen and Young, 1977). Fecal samples (approximately $200 \mathrm{~g}$ wet weight) were collected for each cow from the rectum twice daily (a.m. and p.m.) every $12 \mathrm{~h}$, moving ahead $2 \mathrm{~h}$ each day for the $6 \mathrm{~d}$ of fecal sampling beginning on d 15. This schedule provided 12 representative samples of feces for each cow. Samples were immediately subsampled (about $50 \mathrm{~g}$ ), composited across sampling times for each cow and each period, dried at $55^{\circ} \mathrm{C}$ for $72 \mathrm{~h}$, ground to pass a 1-mm screen (standard model 4), and stored for chemical analysis. Apparent total-tract nutrient digestibilities were calculated from concentrations of AIA and nutrients in diets fed, orts, and feces using the following equation: apparent digestibility = $100-\left[100 \times\left(\mathrm{AIA}_{\mathrm{d}} / \mathrm{AIA}_{\mathrm{f}}\right) \times\left(\mathrm{N}_{\mathrm{f}} / \mathrm{N}_{\mathrm{d}}\right)\right]$, where $\mathrm{AIA}_{\mathrm{d}}=$ AIA concentration in the diet actually consumed, AIA $_{f}$ $=$ AIA concentration in the feces, $\mathrm{N}_{\mathrm{f}}=$ concentration of the nutrient in the feces, and $\mathrm{N}_{\mathrm{d}}=$ concentration of the nutrient in the diet actually consumed (Eun and Beauchemin, 2005).

\section{Ruminal Fermentation Characteristics}

Ruminal pH was continuously measured for 2 consecutive days starting on d 18 using the Lethbridge Research Centre Ruminal pH Measurement System (LRCpH; Dascor, Escondido, CA) as described by Penner et al. (2006). Readings in pH buffers 4 and 7 were recorded before placing the $\mathrm{LRCpH}$ system in the rumen. Ruminal $\mathrm{pH}$ readings were taken every $30 \mathrm{~s}$ and stored by the data logger. After about $48 \mathrm{~h}$ of continuous $\mathrm{pH}$ measurement, the $\mathrm{LRCpH}$ was removed from the rumen and washed in $39^{\circ} \mathrm{C}$ water; millivolt readings were recorded in $\mathrm{pH}$ buffers 4 and 7 . The daily ruminal $\mathrm{pH}$ data were averaged for each minute and summarized as minimum $\mathrm{pH}$, mean $\mathrm{pH}$, and maximum $\mathrm{pH}$. In addition, daily episodes, duration $(\mathrm{h} / \mathrm{d})$, and area $(\mathrm{pH} \times \min )$ when ruminal $\mathrm{pH}$ was $<5.5$ were calculated. The threshold 5.5 was assigned because it has been defined by others (Beauchemin and Yang, 2005) to cause ruminal acidosis.

Ruminal contents were sampled from cannulated cows 0,3 , and $6 \mathrm{~h}$ after the a.m. feeding on d 20 and 21 . Approximately $1 \mathrm{~L}$ of ruminal contents was obtained from the anterior dorsal, anterior ventral, medial ventral, posterior dorsal, and posterior ventral locations within the rumen, composited by cow, and strained through a polyester screen (pore size $355 \mu \mathrm{m}$; B \& S H Thompson, Ville Mont-Royal, QC, Canada). Five milli- 
liters of the filtered ruminal fluid was added to $1 \mathrm{~mL}$ of $1 \%$ sulfuric acid, and samples were retained for $\mathrm{NH}_{3}-\mathrm{N}$ determination. Concentration of $\mathrm{NH}_{3}-\mathrm{N}$ in the ruminal contents was determined as described by Rhine et al. (1998). Another $5 \mathrm{~mL}$ of the filtered ruminal fluid was taken at $3 \mathrm{~h}$ after the a.m. feeding and added to $1 \mathrm{~mL}$ of $25 \%$ of meta-phosphoric acid, and the samples were retained for VFA determination. The VFA were quantified using a GLC (model 6890 series II) with a capillary column $(30 \mathrm{~m} \times 0.32 \mathrm{~mm}$ i.d., $1-\mu \mathrm{m}$ phase thickness, Zebron ZB-FAAP, Phenomenex, Torrance, CA), and flame-ionization detection. Crotonic acid was used as an internal standard. The oven temperature was $170^{\circ} \mathrm{C}$ held for $4 \mathrm{~min}$, which was then increased by $5^{\circ} \mathrm{C} / \mathrm{min}$ to $185^{\circ} \mathrm{C}$, and then by $3^{\circ} \mathrm{C} / \mathrm{min}$ to $220^{\circ} \mathrm{C}$, and held at this temperature for $1 \mathrm{~min}$. The injector temperature was $225^{\circ} \mathrm{C}$, the detector temperature was $250^{\circ} \mathrm{C}$, and the carrier gas was helium.

\section{Statistical Analyses}

Data were summarized for each cow by measurement period. All data were statistically analyzed using the mixed model procedure in SAS (SAS Institute, 2001). Data for intake, BW, digestibility, energy balance, and milk production were analyzed by using a model that included the effects of forage level in the diet (HF vs. LF), square (noncannulated vs. cannulated cows), CTE supplementation (without vs. with CTE), and the interaction between forage level in the diet and CTE. Cow, period, and cow by period by square were the terms of the random statement.

Data for VFA profiles and $\mathrm{NH}_{3}-\mathrm{N}$ concentration were analyzed with a model that included the effects of forage level (HF vs. LF), CTE supplementation (without vs. with CTE), and the interaction between forage level and CTE. In addition, the fixed effect of time after feeding was included using the repeated option. Cow and period were the terms of the random statement. The covariance structure that resulted in the lowest values for the Akaike's information criteria and Schwarz's Bayesian criterion was used (Littell et al., 1998). Data for DMI were reported using the heterogeneous compound symmetry structure, whereas milk yield data were analyzed by the autoregressive structure. Data for milk components and efficiency of feed and $\mathrm{N}$ utilization were analyzed using the unstructured covariance structure. In addition, data for VFA and $\mathrm{NH}_{3}-\mathrm{N}$ were analyzed by the unstructured and unstructured variance-covariance structure.

Residual errors were used to test main effects and interactions. Differences were considered significant at $P<0.05$ and trends were discussed at $P<0.10$. When the interaction between forage level in the diet and CTE was $P<0.10$, contrasts were used to examine the effects of CTE within forage level using single degree of freedom contrasts. Contrasts were considered significant at $P<0.05$. Results are reported as least squares means.

\section{RESULTS AND DISCUSSION}

\section{Characteristics of Experimental Diets}

Ingredients and chemical composition of experimental diets are listed in Table 1. Alfalfa hay was used as the main forage in the HF and LF diets, and the alfalfa hay was high quality, being clean, bright green, and fine stemmed with a chemical composition of 21.7 $\pm 1.68,40.6 \pm 0.09$, and $30.7 \pm 0.27 \% \mathrm{DM}$ for $\mathrm{CP}$, NDF, and ADF, respectively. Therefore, digestive and nutritive contributions by the alfalfa hay in the current study would be relatively high due to its large dietary proportion (31.9 and $24.4 \% \mathrm{DM}$ for the HF and LF diets, respectively) and its high nutritive quality. Corn silage used in this study contained $7.2 \pm 0.70$, $41.7 \pm 1.67$, and $23.4 \pm 1.12 \% \mathrm{DM}$ for $\mathrm{CP}, \mathrm{NDF}$, and $\mathrm{ADF}$, respectively. Concentrations of $\mathrm{CP}$ were similar between the HF and the LF diet, and the RDP to RUP ratio was maintained at 70:30, on average, across diets. Concentrations of NDF and ADF were higher in the HF diet compared with the LF diet, whereas starch concentration was higher in the LF than in the HF diet (29.4 vs. $22.9 \%$ on average).

Fatty acid profiles of experimental diets are presented in Table 2. The concentration of cis-9 C18:1 was higher in the LF diet, whereas C18:3 n-3 was present at a higher concentration in the HF diet. Diets were similar in other FA and total saturated and unsaturated FA.

\section{Intake and Digestibility}

The effects of increasing the forage proportion of the diet observed in this study were as expected based on previous literature (Yang et al., 2001; Eun and Beauchemin, 2005). Yang et al. (2001) reported no difference on DM intake in response to forage-to-concentrate ratios of 35:65 or 55:45 (DM basis) in lactating cows, whereas Eun and Beauchemin (2005) reported that total-tract digestibilities of DM, OM, and NDF were not affected by a forage-to-concentrate ratio of 60:40 vs. 34:66 (DM basis) in lactating cows. The discussion of these effects is limited because the focus of this study was to understand the interaction between level of forage in the diet and CTE supplementation, rather than the effects of forage-to-concentrate ratio per se.

Supplementing CTE in the diet decreased intake of $\mathrm{DM}, \mathrm{OM}, \mathrm{CP}, \mathrm{NDF}$, and $\mathrm{ADF}$, regardless of forage 
Table 2. Fatty acid composition (means \pm SD) of the TMR fed to lactating cows $(n=4)$

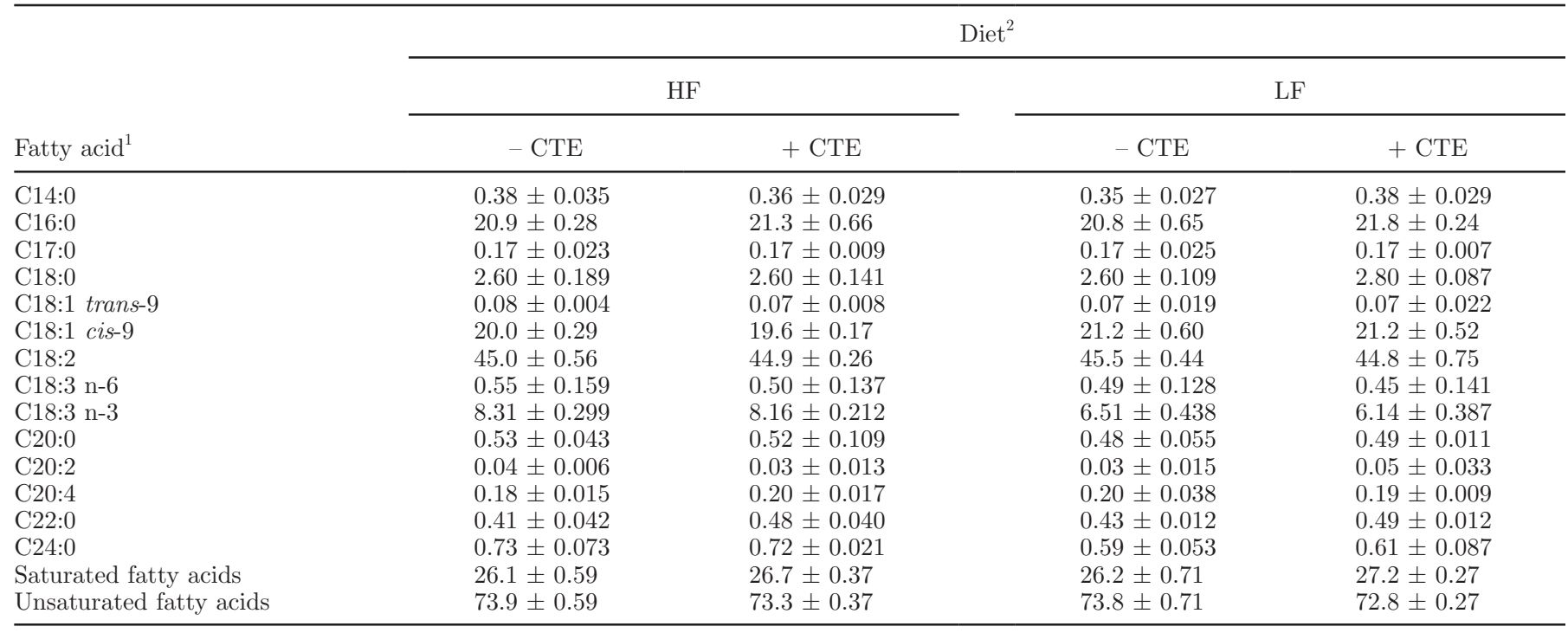

${ }^{1}$ Fatty acid composition expressed as $\mathrm{g} / 100 \mathrm{~g}$ of fatty acid methyl esters.

${ }^{2}$ Diets: high forage (HF) and low forage (LF) with $(+\mathrm{CTE})$ and without $(-\mathrm{CTE})$ condensed tannin extract.

level (Table 3). Previous studies on the effects of CT on feed intake in ruminants have yielded inconsistent results. Decreases of DMI with CT have already been reported either in cows (McNabb et al., 1996 with 5.5\% of CT; Priolo et al., 2000 with $2.5 \%$ of CT) or in sheep (Barry and McNabb, 1999 with 7.5 to $10.0 \%$ of CT). This depressing effect would be attributed to degraded palatability (Cooper and Owen-Smith, 1985) or to a short-term effect of astringency (Landau et al., 2000). Others found no effect of CT on DMI in either Jersey heifers $(0.60 \%$ of quebracho CTE; Baah et al., 2007) or lactating dairy cows $(0.45 \%$ of CT; Benchaar et al., 2008). Conversely, DMI increases were also observed with CT as in Woodward et al. (2001) and Carulla et al. (2005) with 2.59 and $2.50 \%$ of CT, respectively. These results suggest that $\mathrm{CT}$ fed at relatively high concentrations has negative effects on feed intake in ruminants, and the effects may vary with the source of CT.

Although supplementing CTE in the diet decreased feed intake, total-tract digestibilities of DM and nutrients were not affected, regardless of the level of forage in the diet. Similar to our result, Benchaar et al. (2008) observed no effects on digestibilities of DM and nutrients $(\mathrm{OM}, \mathrm{CP}$, and $\mathrm{ADF})$ with the addition of quebracho CTE at $0.64 \%$ of DM. In contrast, Beauchemin et al. (2007) reported that the digestibility of CP decreased in beef cattle with the addition of 1 to $2 \%$ quebracho CTE. Carulla et al. (2005) observed that supplementing the diet of sheep with $2.5 \% \mathrm{DM}$ of CTE from black wattle tree decreased digestibilities of $\mathrm{OM}, \mathrm{CP}, \mathrm{NDF}$, and ADF. Although binding of tannins to protein im- proves efficiency of $\mathrm{N}$ utilization in ruminants (Aerts et al., 1999b), it may influence CP digestibility depending upon concentration and source of tannins. In fact, a diet containing $1.8 \% \mathrm{CT}$ from big trefoil resulted in a reduced $\mathrm{CP}$ digestibility, whereas the same concentration of CT from birdsfoot trefoil had less effect on CP digestibility (Waghorn and Shelton, 1997). Similar to our findings, Baah et al. (2007) reported that digestibilities of DM, OM, and NDF were not altered in LF diets supplemented with quebracho CTE at $0.6 \%$ DM when fed to Jersey heifers. Based on CTE supplementation having no effect on digestibility in this study, it is likely that the quebracho CTE supplementation at $3 \%$ DM in the diets tested in our study simply depressed feed intake due to palatability without affecting feed digestion.

\section{Milk Production and Efficiency}

Milk yield averaged 34.6 and $36.1 \mathrm{~kg} / \mathrm{d}$ for the $\mathrm{HF}$ and LF diets, respectively, and was not influenced by CTE supplementation (Table 4), which agreed with Benchaar et al. (2008) and Aguerre et al. (2010) with lower dietary inclusions of CTE (0.64 and 1.8\%, DM basis, respectively). Concentrations of milk fat, true protein, and lactose were not affected by CTE supplementation. Yield of milk components was not altered by CTE supplementation. Milk fat yield and composition were not affected when supplementing CTE in lactation dairy diets up to $1.8 \%$ DM (Aguerre et al., 2010). Benchaar et al. (2008) reported that milk composition was not changed when supplementing quebracho CTE 
Table 3. Nutrient intake and total-tract digestibility of lactating cows fed high (HF) or low forage (LF) diets without or with condensed tannin extract (CTE) supplementation

\begin{tabular}{|c|c|c|c|c|c|c|c|c|}
\hline Item & \multicolumn{4}{|c|}{ Diet } & SEM & & & \\
\hline \multicolumn{9}{|c|}{ Intake, $\mathrm{kg} / \mathrm{d}$} \\
\hline $\mathrm{DM}$ & 27.7 & 25.4 & 27.5 & 26.3 & 1.25 & 0.53 & $<0.01$ & 0.32 \\
\hline $\mathrm{OM}$ & 24.0 & 22.8 & 24.6 & 23.8 & 1.17 & 0.10 & 0.04 & 0.63 \\
\hline $\mathrm{ADF}$ & 5.75 & 5.39 & 5.12 & 4.89 & 0.287 & $<0.01$ & $<0.01$ & 0.54 \\
\hline \multicolumn{9}{|c|}{ Digestibility, \% } \\
\hline $\mathrm{DM}$ & 68.8 & 65.9 & 71.1 & 70.0 & 2.28 & 0.17 & 0.39 & 0.70 \\
\hline $\mathrm{OM}$ & 70.2 & 67.6 & 72.4 & 71.2 & 2.30 & 0.23 & 0.42 & 0.76 \\
\hline $\mathrm{CP}$ & 70.8 & 67.1 & 73.4 & 70.5 & 3.01 & 0.29 & 0.24 & 0.87 \\
\hline NDF & 53.1 & 51.1 & 55.0 & 54.9 & 3.55 & 0.43 & 0.76 & 0.79 \\
\hline $\mathrm{ADF}$ & 49.8 & 47.5 & 48.1 & 48.7 & 3.89 & 0.95 & 0.82 & 0.72 \\
\hline
\end{tabular}

${ }^{1} \mathrm{FL}=$ forage level in the diet (HF vs. $\mathrm{LF}$ ); CTE = without versus with $\mathrm{CTE}$ supplementation; and $\mathrm{FL} \times \mathrm{CTE}=$ interaction between $\mathrm{FL}$ and CTE.

to lactating dairy cows. When supplementing CTE at different levels, Aguerre et al. (2010) reported that milk true protein concentration increased at $0.45 \%$ CTE supplementation, whereas supplementing CTE at $1.8 \%$ DM decreased milk true protein concentration. It seems that milk composition depends on the concentration of CT in the diet tested, and in our case, CTE supplementation at 3\% DM would have minor effects on milk composition. However, it is not clear how the smaller dose of CTE at 1.8\% DM tested by Aguerre et al. (2010) decreased milk true protein concentration.
Concentration of MUN decreased by 16.9 and $16.2 \%$ in the $\mathrm{HF}$ and $\mathrm{LF}$ diets, respectively, in this study. Milk urea $\mathrm{N}$ decreased by $7.2 \%$ in cows supplemented with CTE at $1.8 \%$ DM, but not at lower concentrations of 0.45 to $0.9 \%$ DM (Aguerre et al., 2010). Likewise, Benchaar et al. (2008) observed no effects of CTE supplemented at $0.64 \%$ of DM on MUN. Although the CP concentration in our diets was relatively high compared with typical lactation diets, the CP concentration and RDP to RUP ratio were similar across diets. Therefore, the effect of CTE supplementation at $3 \%$ of DM used

Table 4. Milk production and composition and efficiencies of DM and N use for milk production of lactating cows fed high (HF) or low forage (LF) diets without or with condensed tannin extract (CTE) supplementation

\begin{tabular}{|c|c|c|c|c|c|c|c|c|}
\hline Item & \multicolumn{4}{|c|}{ Diet } & SEM & & & \\
\hline \multirow{2}{*}{\multicolumn{7}{|c|}{ Milk composition, \% }} & 0.42 & 0.21 \\
\hline $\begin{array}{l}\text { Milk composition, } \% \\
\text { Fat }\end{array}$ & 3.75 & 3.69 & & & & & & \\
\hline MUN, mg/dL & 14.8 & 12.3 & 14.8 & 12.4 & 0.80 & 0.91 & $<0.01$ & 0.96 \\
\hline \multicolumn{9}{|c|}{ Milk component yield, $\mathrm{kg} / \mathrm{d}$} \\
\hline Fat & 1.29 & 1.29 & 1.30 & 1.30 & 0.091 & 0.84 & 0.92 & 0.93 \\
\hline True protein & 1.05 & 1.05 & 1.12 & 1.10 & 0.050 & $<0.01$ & 0.55 & 0.43 \\
\hline Lactose & 1.66 & 1.69 & 1.76 & 1.75 & 0.099 & 0.04 & 0.84 & 0.61 \\
\hline \multicolumn{9}{|l|}{ Efficiency } \\
\hline Milk yield/DMI & $1.23^{\mathrm{b}}$ & $1.37^{\mathrm{a}}$ & 1.33 & 1.37 & 0.071 & 0.05 & $<0.01$ & 0.07 \\
\hline
\end{tabular}

${ }^{\mathrm{a}, \mathrm{b}}$ Means in the same row within HF and LF subgroups with different superscripts differ based on single degree of freedom contrasts $(P<0.05)$. ${ }^{1} \mathrm{FL}=$ forage level in the diet (HF vs. LF); CTE = without versus with CTE supplementation; and FL $\times$ CTE $=$ interaction between FL and CTE.

${ }^{2}$ Efficiency of use of feed $\mathrm{N}$ to milk $\mathrm{N}=[$ (milk true protein, $\left.\mathrm{kg} / \mathrm{d} \div 0.93) \div 6.38\right] \div \mathrm{N}$ intake, $\mathrm{kg} / \mathrm{d}$ (Dschaaka et al., 2010). 
in this study would not be influenced by diets to elicit a positive effect on MUN concentration. Milk urea N is used as a management tool to improve dairy herd nutrition and monitor the nutritional status of lactating dairy cows. Urinary $\mathrm{N}$ excretion has been shown to have a positive linear relationship with MUN (Ciszuk and Gebregziabher, 1994; Jonker et al., 1998). Elevated MUN indicates that excess CP has been fed to the dairy cow for her level of production (Broderick and Clayton, 1997; Jonker et al., 1998). Broderick (1995b) reported that MUN more clearly reflected dietary CP intake than did ruminal ammonia concentration. In our case, however, it is clear that forming CT-protein complexes decreased protein degradation and $\mathrm{NH}_{3}-\mathrm{N}$ production in the rumen as discussed later, resulting in decreased MUN concentration. However, CTE supplementation did not affect milk protein concentration and yield in spite of the decreased MUN in this study. Nelson (1996) suggested that when total milk protein was 3.0 to $3.2 \%$ and MUN concentration was 12 to $16 \mathrm{mg} / \mathrm{dL}$, protein degradability fractions and $\mathrm{NE}_{\mathrm{L}}$ were likely in balance. The MUN concentration and the milk protein concentration in our study were within this range, and CT supplementation clearly decreased MUN concentration. Lower MUN by CTE supplementation suggests that supplementing CTE in lactating dairy diets may reduce $\mathrm{N}$ excretion into urine because urinary $\mathrm{N}$ excretion has been shown to have a positive linear relationship with MUN (Jonker et al., 1998).

Contrary to the effect of CTE on MUN, efficiency of $\mathrm{N}$ use for milk $\mathrm{N}$ was not affected by CTE supplementation (Table 4), probably because CTE did not affect milk protein yield. Feed efficiency (milk yield/DMI) increased by CTE supplementation in the HF diet, but not in the LF diet, leading to a tendency for an interaction between forage level and CTE supplementation $(P=0.07)$. Aguerre et al. (2010) reported that feed efficiency was not influenced by supplementing CTE up to $1.8 \%$ DM. Makkar (2003) indicated that the greater animal performance observed in some studies when animals were fed CT has been related to the protection of dietary protein from rumen microbial degradation, resulting in increased supply of AA to the intestine and greater absorption into blood. However, in our case it is likely that the negative effects of CTE supplementation on feed intake resulted in increased feed efficiency in the HF diet.

\section{Ruminal Fermentation Characteristics}

Feeding the LF diet decreased ruminal $\mathrm{pH}$ with mean ruminal $\mathrm{pH}$ of 6.47 and 6.33 in the HF and the LF diet, respectively (Table 5). Because of the higher starch concentration in the LF diet (Table 1), we expected that the LF diet would decrease ruminal $\mathrm{pH}$. However, no notable depression in ruminal $\mathrm{pH}$ was shown in minimum $\mathrm{pH}$ and $\mathrm{pH}<5.5$. Yang and Beauchemin (2007) fed LF diets (35:65 of forage-to-concentrate ratio) to lactating dairy cows and observed mean ruminal $\mathrm{pH}$ of 6.02 with area under $\mathrm{pH} 5.5 \times$ min of 75 , whereas feeding the LF diet in this study resulted in area under $\mathrm{pH} 5.5 \times$ min of 1.73 . Although we used barley grain as a main ingredient of the concentrate mixture, dietary concentration of the barley grain was $35.5 \% \mathrm{DM}$ in this study, which is notably lower than that of LF diet (56.1\% DM) tested by Yang and Beauchemin (2007). Thus, the relatively low dietary concentration of barley grain in the LF diet and proper particle size distributions of the diet prevented the decrease in ruminal $\mathrm{pH}$.

Supplementation of CTE did not influence ruminal $\mathrm{pH}$ in the HF or LF diet (Table 5). Similar to our results, Benchaar et al. (2008) and Aguerre et al. (2010) reported no effects on ruminal $\mathrm{pH}$ by feeding CTE to dairy cows. We could not test effects of CTE supplementation on its potential to prevent ruminal acidosis by reducing rapid starch hydrolysis, because feeding the LF diet did not create a severely acidotic fermentative environment in the rumen.

Supplementation of CTE decreased total VFA concentration regardless of the level of forage in the diet (Table 5). Decreased VFA production corresponds to the decreased DMI in this study. Molar proportions of acetate, propionate, and butyrate increased in the $\mathrm{HF}$ diet, but not in the LF diet due to CTE supplementation, resulting in interactions between forage level and CT supplementation. Supplementing CTE in the HF diet decreased the acetate-to-propionate $(\mathbf{A}: \mathbf{P})$ ratio, but in the LF diet, CT supplementation increased the $\mathrm{A}: \mathrm{P}$ ratio, resulting in an interaction between forage level and CT supplementation. Effects of CTE on total VFA concentration and VFA pattern have been variable among studies depending on the dosage rate and the source of CT. For example, Beauchemin et al. (2007) reported that despite a lack of effect of quebracho CTE supplementation on digestibility of DM, increasing supplementation levels of quebracho CTE (up to $2 \%$ of DMI) tended $(P=0.08)$ to decrease total VFA concentration, and decreased acetate molar proportion and $\mathrm{A}: \mathrm{P}$ ratio. In contrast, despite a decrease in digestibility of OM, Carulla et al. (2005) observed no change in total VFA concentration in sheep supplemented with black wattle tree CTE, but the molar proportion of acetate decreased, and that of propionate increased in sheep fed diets supplemented with CTE. Benchaar et al. (2008) and Aguerre et al. (2010) reported that total concentrations of VFA and molar proportions of individual VFA were not affected by feeding quebracho CTE. 
Table 5. Ruminal fermentation characteristics of lactating cows fed high (HF) or low forage (LF) diets without or with condensed tannin extract (CTE) supplementation

\begin{tabular}{|c|c|c|c|c|c|c|c|c|}
\hline Item & \multicolumn{4}{|c|}{ Diet } & SEM & & & \\
\hline Minimum pH & 5.63 & 5.45 & 5.39 & 5.30 & 0.152 & 0.02 & 0.73 & 0.71 \\
\hline Mean pH & 6.43 & 6.50 & 6.33 & 6.33 & 0.080 & $<0.01$ & 0.38 & 0.35 \\
\hline Maximum $\mathrm{pH}$ & 7.01 & 7.07 & 6.93 & 6.89 & 0.074 & 0.02 & 0.84 & 0.27 \\
\hline Duration, h/d & 0.00 & 0.06 & 0.19 & 0.29 & 0.161 & 0.12 & 0.54 & 0.85 \\
\hline Area, $\mathrm{pH} \times \min$ & 0.00 & 0.17 & 1.17 & 2.28 & 1.193 & 0.14 & 0.53 & 0.64 \\
\hline Total VFA, $\mathrm{m} M$ & 129.5 & 121.8 & 137.0 & 131.9 & 3.44 & $<0.01$ & 0.03 & 0.64 \\
\hline Individual $\mathrm{VFA}^{2}$ & & & & & & & & \\
\hline Acetate $(\mathrm{A})$ & $64.3^{\mathrm{b}}$ & $65.9^{\mathrm{a}}$ & 57.9 & 58.9 & 0.96 & $<0.01$ & 0.09 & $<0.01$ \\
\hline Propionate (P) & $18.7^{\mathrm{b}}$ & $20.3^{\mathrm{a}}$ & 25.7 & 24.4 & 0.69 & $<0.01$ & 0.65 & 0.01 \\
\hline Butyrate & $10.5^{\mathrm{b}}$ & $11.5^{\mathrm{a}}$ & 13.0 & 13.6 & 0.49 & $<0.01$ & 0.16 & $<0.01$ \\
\hline
\end{tabular}

${ }^{\mathrm{a}, \mathrm{b}}$ Means in the same row within HF and LF subgroups with different superscripts differ based on single degree of freedom contrasts $(P<0.05)$. ${ }^{1} \mathrm{FL}=$ forage level in the diet (HF vs. LF); CTE = without versus with CTE supplementation; and $\mathrm{FL} \times \mathrm{CTE}=$ interaction between FL and CTE.

${ }^{2}$ Expressed as mol/100 mol.

An interesting finding of this experiment was that molar proportions of VFA were affected by CTE in the HF diet, but not in the LF diet. In addition, CTE supplementation decreased the A:P ratio in the $\mathrm{HF}$ diet, whereas CTE supplementation increased A:P ratio in the LF diet. The mechanism whereby CTE supplementation resulted in an opposite effect on A:P ratio between the HF and LF diets is difficult to explain. Supplementing CTE would beneficially manipulate ruminal fermentation in the HF diet that contained a higher dietary proportion of alfalfa hay compared with the LF diet that contained a higher level of steamflaked barley. A favorable change in A:P ratio in the HF diet due to CTE supplementation may contribute to the increasing feed efficiency discussed earlier. The differences in the A:P ratio between the $\mathrm{HF}$ and the LF diets detected in this study may be due to several factors, such as ruminal bacterial growth rates due to different starch concentrations between the HF and the LF diet, substrate affinities with CT (alfalfa hay protein vs. barley protein), or microbial inhibition. Further research needs to elucidate how CTE supplementation would beneficially affect ruminal fermentation in $\mathrm{HF}$ diets, particularly diets containing high dietary proportions of alfalfa hay.

The concentration of $\mathrm{NH}_{3}-\mathrm{N}$ tended to decrease ( $P$ $=0.09$ ) with supplementation of CTE (Table 5). A decrease in $\mathrm{NH}_{3}-\mathrm{N}$ concentration was reported when $\mathrm{CTE}$ was supplemented at $1.8 \% \mathrm{DM}$, whereas no effects were observed at a lower concentration (0.45 and 0.9\% DM; Aguerre et al., 2010). Moreover, a diet containing 1.8\% of CT from big trefoil resulted in a decreased ruminal $\mathrm{NH}_{3}-\mathrm{N}$ concentration, whereas the same concentration of CT from birdsfoot trefoil had lesser effects (Waghorn and Shelton, 1997). The N-binding effects of CT have been well documented (Waghorn et al., 1987; Barry and McNabb, 1999; Beauchemin et al., 2007). The CT present in birdsfoot trefoil have been found to inhibit the growth of proteolytic bacteria and may also precipitate plant protein, making it less available for proteolysis (Min et al., 2000; Molan et al., 2001), thereby inhibiting $\mathrm{NH}_{3}$ production. When protein is rapidly degraded in the rumen, $\mathrm{NH}_{3}$ is produced more quickly than the microbes can utilize it for protein synthesis, resulting in more protein being degraded than synthesized (Broderick, 1995a). Powell et al. (2009) recently reported a shift of $\mathrm{N}$ excretion routes by feeding CT-containing forages, because the ratio of $\mathrm{N}$ excreted in feces and urine was greatest for low-tannin and high-tannin birdsfoot treatments and lowest for alfalfa treatment. Reduced excretion of urinary $\mathrm{N}$ would result in reduced environmental losses through nitrate leaching, $\mathrm{NH}_{3}$ volatilization, and nitrous oxide emissions (Place and Mitloehner, 2010). Because supplementation of CTE had no effect on $\mathrm{N}$ utilization efficiency for milk production in this study, supplementation of CTE in lactation dairy diets may change the route of $\mathrm{N}$ excretion, having less excretion into urine but more into feces. 
Table 6. Fatty acid composition in the milk of lactating cows fed high (HF) or low forage (LF) diets without or with condensed tannin extract (CTE) supplementation

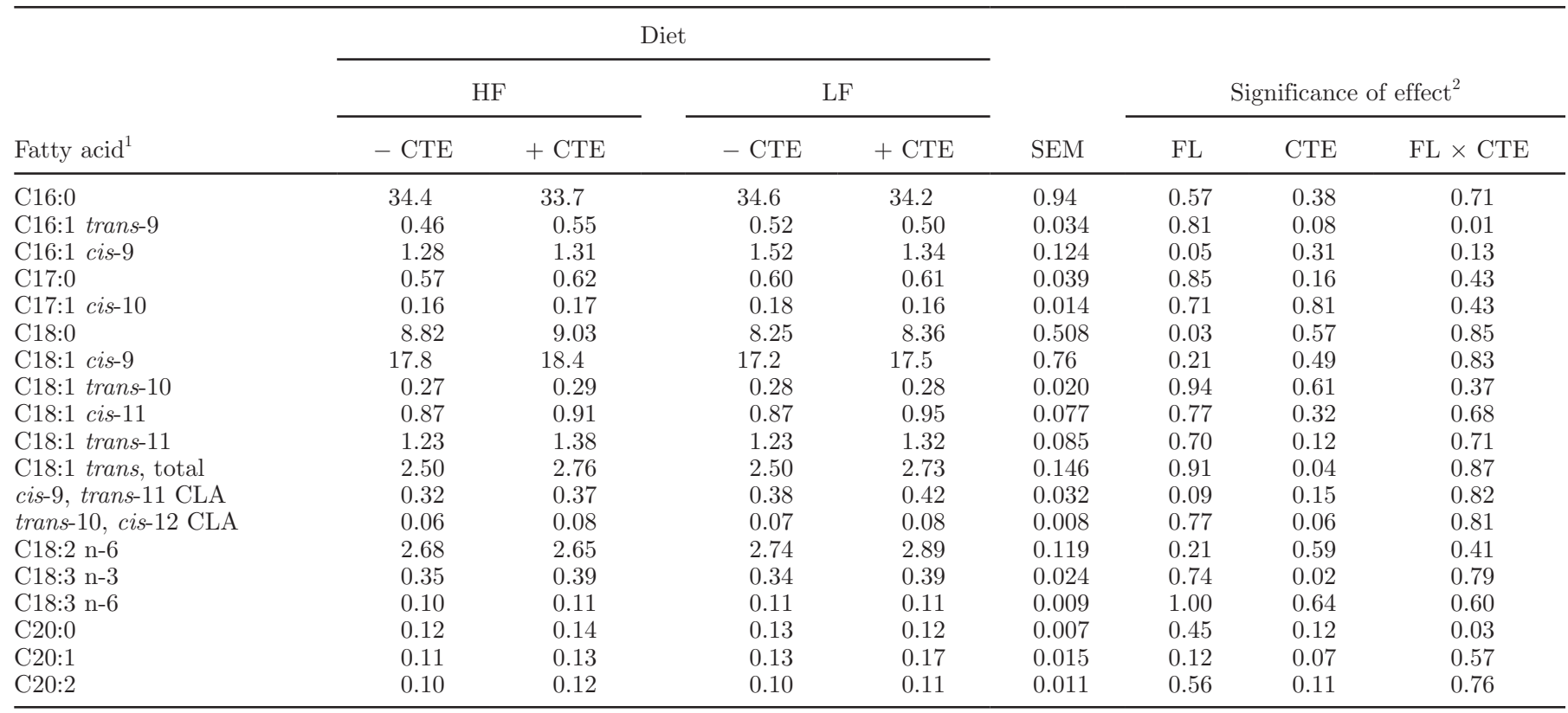

${ }^{1}$ Fatty acid composition was expressed as g/100 g of fatty acid methyl esters. C18:1 trans, total = trans- $4,5 \mathrm{C} 18: 1+$ trans-6,8 C18:1 + trans-9 C18:1 + trans-10 C18:1 + trans-11 C18:1 + trans-12 C18:1 + trans-13,14 C18:1; CLA = conjugated linoleic acid.

${ }^{2} \mathrm{FL}=$ forage level in the $\operatorname{diet}(\mathrm{HF}$ vs. $\mathrm{LF}) ; \mathrm{CTE}=$ without versus with $\mathrm{CTE}$ supplementation; and $\mathrm{FL} \times \mathrm{CTE}=$ interaction between $\mathrm{FL}$ and CTE.

It is also possible that the tendency on lower ruminal $\mathrm{NH}_{3}-\mathrm{N}$ with $\mathrm{CTE}$ supplementation was due in part to the lower CP intake as reported in Table 3.

\section{Milk FA Composition}

In general, supplementation of CTE had minor effects on milk FA profiles regardless of forage level in the diet (Table 6). Concentration of total C18:1 trans FA increased with CTE supplementation. Cows fed CTE-supplemented diets tended to increase $(P=0.06)$ trans-10, cis-12 CLA. Supplementing CTE increased the proportion of C18:3 n-3 FA regardless of forage level. In addition, supplementing $\mathrm{CT}$ tended to increase $(P=$ 0.07) C20:1 FA. Limited information exists on the use of CTE to alter the ruminal biohydrogenation process and manipulate the FA profile of bovine milk and meat. Benchaar and Chouinard (2009) reported that milk FA composition was not affected by supplementing quebracho CTE. Jones et al. (1994) showed inhibition of the growth of $B$. fibrisolvens, which is involved in ruminal biohydrogenation of FA. Using 24 -h in vitro batch culture, Kronberg et al. (2007) reported that quebracho CTE reduced biohydrogenation of C18:3 FA. Using continuous cultures, Khiaosa-Ard et al. (2009) reported an inhibition of the last step of biohydrogenation by CTE supplied at a rate of $7.89 \% \mathrm{DM}$, leading to the accumulation of trans-11 C18:1 FA. It is likely that the CTE supplementation at 3\% DM tested in this study would not interfere in the biohydrogenation process in the rumen and consequently have no major effect on FA profiles in the milk.

\section{CONCLUSIONS}

Experimental cows used in this study maintained overall productive performance without any negative response on digestibility, milk production, and ruminal fermentation when cows were fed CTE-supplemented diets. Condensed tannins decreased intakes of DM and nutrients, but CT improved feed efficiency in the HF diet. The greater response to CTE supplementation in the HF diet may have resulted from a higher dietary proportion of alfalfa hay in the HF diet, which highlights that CTE supplementation needs to be focused on diets containing high forage $\mathrm{N}$ degradability in the rumen. The most significant findings in this study were that cows receiving CTE-supplemented diets decreased ruminal $\mathrm{NH}_{3}-\mathrm{N}$ and MUN concentrations without loss of milk protein yield. This indicates that less ruminal $\mathrm{N}$ was lost as $\mathrm{NH}_{3}$ because of decreased $\mathrm{CP}$ degradation by rumen microorganisms in response to CTE supplementation. Therefore, dietary manipulation with the use of CTE in dairy diets may alter ruminal metabo- 
lism and $\mathrm{N}$ excretion into urine. Because of a lack of effect on $\mathrm{N}$ utilization efficiency, the benefit may be an increase of $\mathrm{N}$ excretion into feces, a more stable form of $\mathrm{N}$, influencing the ratio of fecal $\mathrm{N}$ to urinary $\mathrm{N}$, but not total $\mathrm{N}$ excretion.

\section{ACKNOWLEDGMENTS}

This study was supported by fund from the Research Catalyst Program at the Vice President for Research Office, Utah State University (Logan). Additional support was provided by the Utah Agricultural Experiment Station, Utah State University. We thank S. Durham (Ecology Center, Utah State University) for assistance with statistical analysis of the results and the staff of the Caine Dairy Center, Utah State University (Wellsville) for their conscientious care of the experimental cows. We are also grateful for the constructive comments and advice by two reviewers and section editor S. Calsamiglia on the manuscript.

\section{REFERENCES}

Aerts, R. J., T. N. Barry, and W. C. McNabb. 1999b. Polyphenols and agriculture: Beneficial effects of proanthocyanidins in forages. Agric. Ecosyst. Environ. 75:1-12.

Aerts, R. J., W. C. McNabb, A. Molan, A. Brand, J. S. Peters, and T. N. Barry. 1999a. Condensed tannins from Lotus corniculatus and Lotus pedunculatus effect the degradation of ribulose 1,5-bisphosphate carboxylase (Rubisco) protein in the rumen differently. J. Sci. Food Agric. 79:79-85.

Aguerre, M. J., M. A. Wattiaux, M. C. Capozzolo, P. Lencioni, and C. Cabral. 2010. Effect of quebracho-chestnut tannin extracts at two dietary crude protein levels on performance and rumen fermentation of dairy cows. J. Dairy Sci. 93(Suppl. 1):445. (Abstr.)

AOAC. 2000. Official Methods of Analysis. Vol. 1 and 2. 17th ed. AOAC Int., Gaithersburg, MD.

Baah, J., M. Ivan, A. N. Hristov, K. M. Koenig, L. M. Rode, and T. A. McAllister. 2007. Effects of potential dietary antiprotozoal supplements on rumen fermentation and digestibility in heifers. Anim. Feed Sci. Technol. 137:126-137.

Barry, T. N., and W. C. McNabb. 1999. The implications of condensed tannins on the nutritive value of temperate forages fed to ruminants. Br. J. Nutr. 81:263-272.

Beauchemin, K. A., S. M. McGinn, T. F. Martinez, and T. A. McAllister. 2007. Use of condensed tannin extract from quebracho trees to reduce methane emissions from cattle. J. Anim. Sci. 85:19901996.

Beauchemin, K. A., and W. Z. Yang. 2005. Effects of physically effective fiber on intake, chewing activity, and ruminal acidosis for dairy cows fed diets based on corn silage. J. Dairy Sci. 88:2117-2129.

Benchaar, C., and P. Y. Chouinard. 2009. Short communication: Assessment of the potential of cinnamaldehyde, condensed tannins, and saponins to modify milk fatty acid composition of dairy cows. J. Dairy Sci. 92:3392-3396.

Benchaar, C., T. A. McAllister, and P. Y. Chouinard. 2008. Digestion, ruminal fermentation, ciliate protozoal populations, and milk production from dairy cows fed cinnamaldehyde, quebracho condensed tannin, or Yucca schidigera saponin extract. J. Dairy Sci. 91:4765-4777.

Broderick, G. A. 1995a. Desirable characteristics of forage legumes for improving protein utilization in ruminants. J. Anim. Sci. $73: 2760-2773$.
Broderick, G. A. 1995b. Performance of lactating dairy cows fed either alfalfa silages or alfalfa hay as the sole forage. J. Dairy Sci. 78:320-329.

Broderick, G. A., and M. K. Clayton. 1997. A statistical evaluation of animal and nutritional factors influencing concentrations of milk urea nitrogen. J. Dairy Sci. 80:2964-2971.

Carulla, J. E., M. Kreuzer, A. Machmüller, and H. D. Hess. 2005. Supplementation of Acacia mearnsii tannins decreases methanogenesis and urinary nitrogen in forage-fed sheep. Aust. J. Agric Res. 56:961-970.

Chouinard, P. Y., L. Corneau, D. M. Barbano, L. E. Metzger, and D. E. Bauman. 1999. Conjugated linoleic acid alters milk fatty acid composition and inhibits milk fat secretion in dairy cows. J. Nutr. 129:1579-1584

Ciszuk, A. U., and T. Gebregziabher. 1994. Milk urea as an estimate of urine nitrogen of dairy cows and goats. Acta Agric. Scand. 44:87-95.

Cooper, S. M., and N. Owen-Smith. 1985. Condensed tannins deter feeding by browsing ungulates in a South African savanna. Oecologia 67:142-146.

Dschaaka, C. M., J.-S. Eun, A. J. Young, and J. W. Bergman. 2010. Nutritive merits of whole Nutrasaff safflower seed when fed to Holstein dairy cows during midlactation. Anim. Feed Sci. Technol. 156:26-36.

Eun, J.-S., and K. A. Beauchemin. 2005. Effects of a proteolytic feed enzyme on intake, digestion, ruminal fermentation, and milk production. J. Dairy Sci. 88:2140-2153.

Hurley, W. L., G. J. Warner, and R. R. Grummer. 1987. Changes in triglyceride fatty acid composition of mammary secretions during involution. J. Dairy Sci. 70:2406-2410.

Hymes-Fecht, U. C., G. A. Broderick, and R. E. Muck. 2005. Effects of feeding legume silage with differing tannin levels on lactating dairy cattle. Page 163 in Proc XIV Intl. Silage Conf, a satellite workshop of the XXth Intl. Grassl. Congr., Belfast, UK.

Jenkins, T. C., R. J. Wallace, P. J. Moate, and E. E. Mosley. 2008. Recent advances in biohydrogenation of unsaturated fatty acids within the rumen microbial ecosystem. J. Anim. Sci. 86:397-412.

Jones, G. A., T. A. McAllister, A. D. Muir, and K. Cheng. 1994. Effects of sainfoin (Onobrychis viciifolia Scop.) condensed tannins on growth and proteolysis by four strains of ruminal bacteria. Appl Environ. Microbiol. 60:1374-1378.

Jonker, J. S., R. A. Kohn, and R. A. Erdman. 1998. Using milk urea nitrogen to predict nitrogen excretion and utilization efficiency in lactating dairy cattle. J. Dairy Sci. 81:2681-2692.

Khiaosa-Ard, R. S. F. Bryner, M. R. L. Scheeder, H. R. Wettstein, F. Leiber, M. Kreuzer, and C. R. Soliva. 2009. Evidence for the inhibition of the terminal step of ruminal $\alpha$-linolenic acid biohydrogenation by condensed tannins. J. Dairy Sci. 92:177-188.

Kleinschmit, D. H., D. J. Schingoethe, A. R. Hippen, and K. F. Kalscheur. 2007. Dried distillers grains plus solubles with corn silage or alfalfa hay as the primary forage source in dairy cow diets. J Dairy Sci. 90:5587-5599.

Kononoff, P. J., and A. J. Heinrichs. 2007. Evaluating particle size of forages and TMRs using the New Penn State Forage Particle Separator. Penn State, College of Agricultural Sciences, Cooperative Extension, DAS 02-42. Accessed July 1, 2010. http://www. das.psu.edu/research-extension/dairy/nutrition/pdf/evaluatingparticle-size-of-forages.pdf.

Kononoff, P. J., A. J. Heinrichs, and D. A. Buckmaster. 2003. Modification of the Penn State forage and TMR separator and the effects of moisture content on its measurements. J. Dairy Sci 86:1858-1863

Kronberg, S. L., E. J. Scholljegerdes, G. Barceló-Coblijn, and E. J. Murphy. 2007. Flaxseed treatments to reduce biohydrogenation of alpha-linolenic acid by rumen microbes in cattle. Lipids 42:11051111.

Landau, S., A. Perevolotsky, D. Bonfil, D. Barkai, and N. Silanikove. 2000. Utilization of low quality resources by small ruminants in Mediterranean agro-pastoral systems: The case of browse and aftermath cereal stubble. Livest. Prod. Sci. 64:39-49. 
Littell, R. C., P. R. Henry, and C. B. Ammerman. 1998. Statistical analysis of repeated measures data using SAS procedures. J. Anim. Sci. 76:1216-1231.

Makkar, H. P. S. 2003. Effects and fate of tannins in ruminant animals, adaptation to tannins, and strategies to overcome detrimental effects of feeding tannin-rich feeds. Small Rumin. Res. 49:241-256.

McNabb, W. C., G. C. Waghorn, J. S. Peter, and T. N. Barry. 1996. The effect of condensed tannins in Lotus pedunculatus on the solubilization of ribulose-1,5-bisphosphate carboxylase (EC 4.1.1.39) protein in the rumen and the sites of Rubisco digestion. Br. J. Nutr. 76:535-549.

Min, B. R., G. T. Attwood, K. Reilly, W. Sun, J. S. Peters, T. N. Barry, and W. C. McNabb. 2002. Lotus corniculatus condensed tannins decrease in vivo populations of proteolytic bacteria and affect nitrogen metabolism in the rumen of sheep. Can. J. Microbiol. 48:911-921.

Min, B. R., W. C. McNabb, T. N. Barry, and J. S. Peters. 2000. Solubilization and degradation of ribulose-1,5-bisphosphate carboxylase/oxygenase (EC 4.1.1.39; Rubisco) protein from white clover (Trifolium repens) and Lotus corniculatus by rumen microorganisms and the effect of condensed tannins on these processes. J. Agric. Sci. (Camb.) 134:305-317.

Min, B. R., W. E. Pinchak, R. C. Anderson, J. D. Fulford, and R. Puchala. 2006. Effects of condensed tannins supplementation level on weight gain and in vitro and in vivo bloat precursors in steers grazing winter wheat. J. Anim. Sci. 84:2546-2554.

Molan, A. L., G. T. Attwood, B. R. Min, and W. C. McNabb. 2001. The effect of condensed tannins from Lotus pedunculatus and Lotus corniculatus on the growth of proteolytic rumen bacteria in vitro and their possible mode of action. Can. J. Microbiol. 47:626633.

National Research Council. 2001. Nutrient Requirements of Dairy Cattle. 7th rev. ed. Natl. Acad. Sci., Washington, DC.

Nelson, A. 1996. Practical applications of MUN analyses. Bovine Pract. 29:85-95.

Penner, G. B., K. A. Beauchemin, and T. Mutsvangwa. 2006. An evaluation of the accuracy and precision of a stand-alone submersible continuous ruminal $\mathrm{pH}$ measurement system. J. Dairy Sci. 89:2132-2140.

Place, S. E., and F. M. Mitloehner. 2010. Invited review: Contemporary environmental issues: A review of the dairy industry's role in climate change and air quality and the potential of mitigation through improved production efficiency. J. Dairy Sci. 93:34073416.

Powell, J. M., G. A. Broderick, J. H. Grabber, and U. C. Hymes-Fecht. 2009. Technical note: Effects of forage protein-binding polyphenols on chemistry of dairy excreta. J. Dairy Sci. 92:1765-1769.
Priolo, A., G. C. Waghorn, M. Lanza, L. Biondi, and P. Pennisi. 2000. Polyethylene glycol as a means for reducing the impact of condensed tannins in carob pulp: Effects on lamb growth performance and meat quality. J. Anim. Sci. 78:810-816.

Rhine, E. D., G. K. Sims, R. L. Mulvaney, and E. J. Pratt. 1998. Improving the Bertholot reaction for determining ammonium in soil extracts and water. Soil Sci. Soc. Am. J. 62:473-480.

Rode, L. M., W. Z. Yang, and K. A. Beauchemin. 1999. Fibrolytic enzyme supplementations for dairy cows in early lactation. J. Dairy Sci. 82:2121-2126.

SAS Institute. 2001. SAS System for Microsoft Windows. Release 8.2. SAS Institute Inc., Cary, NC.

Sukhija, P. S., and D. L. Palmquist. 1988. Rapid method for determination of total fatty acid content and composition of feedstuffs and feces. J. Agric. Food Chem. 36:1202-1206.

Turner, S.-A., G. C. Waghorn, S. L. Woodward, and N. A. Thomson. 2005. Condensed tannins in birdsfoot refoil (Lotus corniculatus) affect the detailed composition of milk from dairy cows. Proc. N.Z Soc. Anim. Prod. 65:283-289.

Van Keulen, J., and B. A. Young. 1977. Evaluation of acid-insoluble ash as a natural marker in ruminant digestibility studies. J. Anim. Sci. $44: 282-287$.

Van Soest, P. J., J. B. Robertson, and B. A. Lewis. 1991. Methods of dietary fiber, neutral detergent fiber and non-starch polysaccharides in relation to animal nutrition. J. Dairy Sci. 74:3583-3597.

Vasta, V., A. Nudda, A. Cannas, M. Lanza, and A. Priolo. 2008. Alternative feed resources and their effects on the quality of meat and milk from small ruminants. Anim. Feed Sci. Technol. 147:223246.

Waghorn, G. C., and I. D. Shelton. 1997. Effect of condensed tannins in Lotus corniculatus on the nutritive value of pasture for sheep. J. Agric. Sci. (Camb.) 128:365-372.

Waghorn, G. C., M. J. Ulyatt, A. John, and M. T. Fisher. 1987. The effect of condensed tannins on the site of digestion of amino acids and other nutrients in sheep fed on Lotus corniculatus L. Br. J. Nutr. 57:115-126.

Woodward, S. L., G. C. Waghorn, M. J. Ulyatt, and K. R. Lassey. 2001. Early indications that feeding Lotus will reduce methane emissions from ruminants. Proc. N.Z. Soc. Anim. Prod. 61:23-26.

Yang, W. Z., and K. A. Beauchemin. 2007. Altering physically effective fiber intake through forage proportion and particle length: Chewing and rumen pH. J. Dairy Sci. 90:2826-2838.

Yang, W. Z., K. A. Beauchemin, and L. M. Rode. 2001. Effects of grain processing, forage to concentrate ratio, and forage particle size on rumen $\mathrm{pH}$ and digestion by dairy cows. J. Dairy Sci. $84: 2203-2216$. 